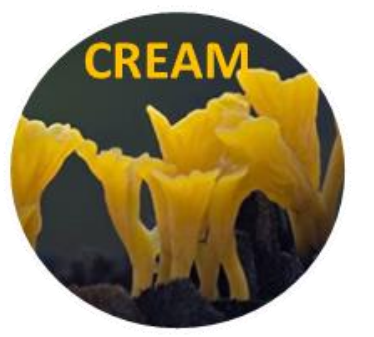

\title{
Ethnomycological survey of the Kalanguya indigenous community in Caranglan, Nueva Ecija, Philippines
}

\section{De Leon $\mathrm{AM}^{1,2}$, Kalaw $\mathrm{SP}^{1,2}$, Dulay $\mathrm{RM}^{1,2}$, Undan $\mathrm{JR}^{1,2}$, Alfonzo $\mathrm{DO}^{2}$, Undan $\mathrm{JQ}^{2}$ and Reyes RG $^{1,2}$}

${ }^{1}$ Department of Biological Sciences, College of Arts and Sciences, Central Luzon State University, Science City of Muñoz, Nueva Ecija, 3119, Philippines

${ }^{2}$ Tuklas Lunas Center, College of Arts and Sciences, Central Luzon State University, Science City of Muñoz, Nueva Ecija, 3119, Philippines

De Leon AM, Kalaw SP, Dulay RM, Undan JR, Alfonzo DO, Undan JQ, Reyes RG 2016 Ethnomycological survey of the Kalanguya indigenous community in Caranglan, Nueva Ecija, Philippines. Current Research in Environmental \& Applied Mycology 6(1), 61-66, Doi $10.5943 / \mathrm{cream} / 6 / 2 / 1$

\begin{abstract}
We documented the indigenous beliefs and utilization of macrofungi by the Kalanguya tribe. To perform the ethnomycological survey of macrofungi utilized by the Kalanguya indigenous community in Sitio Binbin, Brgy. General Luna, Carranglan, Nueva Ecija, the community members and their chieftain were asked to answer survey questionnaires pertaining to their beliefs and knowledge on mushroom utilization, collection and cultivation. Then, collection of the utilized macrofungi were performed during the rainy season. Results showed that most of indigenous people knew about mushrooms, which they locally called as bagel and buo, and utilized for food. There were 36 species claimed by the community as edible, however, only 10 species were obtained during the collection. Based on molecular identification, five mushrooms were identified to species level, namely: Meripilus giganteus, Scleroderma citrinum, Leucoagaricus cepaestipes, Podocypha brasiliensis and Russula virescens, while one mushroom was identified to genus level (Microporus sp.). One interesting finding is that one species of mushroom is used as insect repellant, which is unique since most macrofungi are utilized either as food or medicine. The community does not have any indigenous beliefs when it comes to collection, cultivation as well as utilization. They merely collect the macrofungi from the mountain and utilized them for food or sell them in the market.
\end{abstract}

Key words - Ethnomycology - indigenous community - Kalanguya - macrofungi - mushroom

\section{Introduction}

The sanctuary of the Kalanguya tribes is located in the mountainous areas of Northern Luzon, Philippines. The government has declared most of these mountain areas either as forest reserves, watersheds or national parks. The Kalanguya tribes live in the mountain range of Caranglan in Nueva Ecija, others live on the other side of the mountain range covering portions of Pangasinan, then upstream to Benguet Province and then upward to Ifugao (Dulunan, 2014).

In Nueva Vizcaya, the Kalanguya tribe is the dominant tribe of the municipalities of Ambaguio, Kayapa and Sta. Fe, some communities of Aritao, Dupax del Norte and del Sur, Bambang, Quezon, 
Alfonso Castañeda and Kasibu. In Nueva Ecija, members of the Kalanguya tribe are found in barangays Capintalan, Putlan, Minuli, Salazar, and Binbin of the Municipality of Caranglan. In Pangasinan, they are situated in Barangay Malico, San Nicolas, in some parts of the town of Natividad, others are living in the mountain areas of Umingan and Pozzurubio. The Kalanguyas in Benguet Province are mostly found in the Municipalities of Buguias, Kabayan, Bukod and some parts of Tuba, Itogon, Atok and La Trinidad. A small group of Kalanguya families also currently reside in Doga, Kalinga Apayao; Alicia, Isabela; Cabaroguis, Quirino and in some parts of Aurora Province. All these municipalities can be reached through rugged roads or foot trails (Cayat, 2013).

The Kalanguya ethno-linguistic group maintains a unique cultural identity through language, customs and traditions. They believe in a supernatural being which they call "Kabunyan". Kabunyan to them is the Almighty and Creator. However, since they have not yet seen Kabunyan, they also refer to Him as "Agmattebew" (could not be seen or spirit). During planting and harvesting, birth and death of people and other activities for livelihood, the "Mabaki," (Ritual/Prayer Leader) ask Kabunyan for help (NCIP, 2008).

The Philippine government has identified the Kalanguya in general to be living below the poverty line. A study of their lifestyle, show that they have developed indigenous institutions and have a simple, sustainable economic system. With the advent of the cash economy, the Kalanguya lifestyle began to yield to certain commercial motivations. The indigenous life system where ecological concerns were protected is gradually vanishing. With this development, our objectives are to document the indigenous beliefs and utilization of macrofungi by the Kalanguya tribe before these become extinct because of modernization. Once documented, we might help the community to alleviate poverty by teaching them proper cultivation of wild edible macrofungi which could augment family incomes. Also, their indigenous knowledge could be preserved for the benefit of their younger generation, who are no longer familiar with the traditional knowledge and beliefs of their culture.

\section{Materials \& Methods}

\section{Study Site}

The study site is in Sitio Binbin, Brgy. General Luna, Caranglan, Nueva Ecija (Fig 1). Caranglan is a first class municipality in the province of Nueva Ecija, Philippines. It is the province's largest municipality in terms of land area. Geographical coordinates are $15^{\circ} 57^{\prime} 38^{\prime \prime}$ North, $121^{\circ} 3^{\prime} 50^{\prime \prime}$ East.

\section{Respondents}

The Kalanguya indigenous communities living in Brgy. Gen Luna, Sitio Binbin served as the respondents. Twenty respondents participated in the focused group discussion and survey interview. They were selected based on their knowledge and availability.

\section{Survey Questionnaire and Interview}

A questionnaire was devised for the survey. This questionnaire was prepared in Filipino since the respondents are fluent in the language aside from their native dialect. The questionnaire is designed to generate information about the ethnomycological importance of macrofungi in the aspects of their lives. The data with the survey and interview were tabulated.

\section{Collection and Identification of Edible Mushrooms}

Collection of macrofungi that are most commonly used by the Kalanguya communities was carried out during the rainy season (July 2014) with the help of the chieftain of the tribe. Macrofungi were collected at their fruiting stage and were photographed in situ. After taking the photographs, the fruit bodies were dug carefully so as not to damage their bases. Wood rotting mushrooms were scraped from the bark on which they were attached. The specimens were then coded and wrapped in wax paper in order to avoid excess humidity. Identification of the collected mushrooms were done using internal transcribe spacer region (ITS marker) following the standard protocol for molecular identification. 


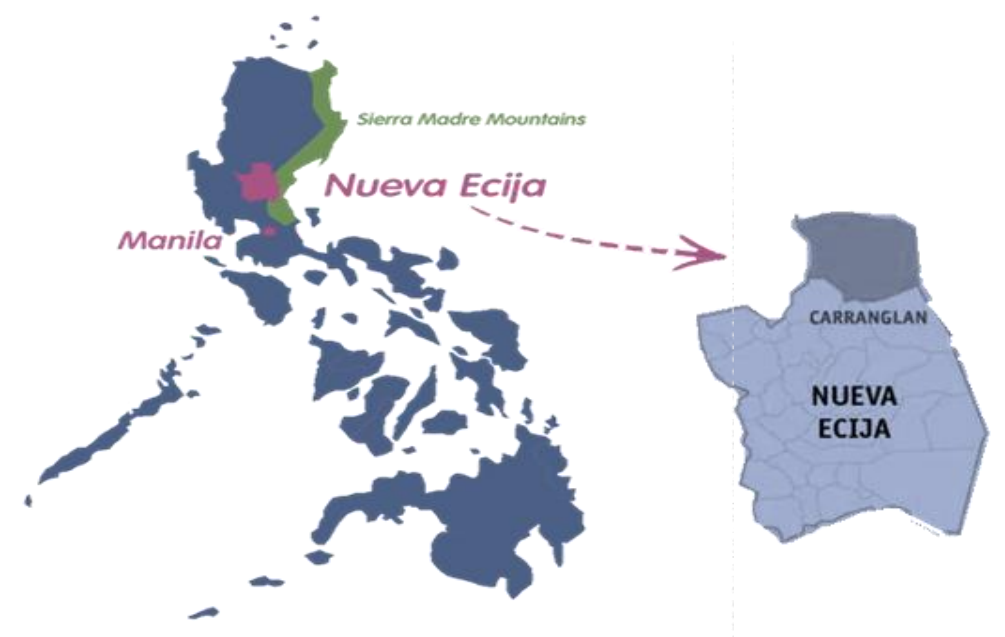

Fig. 1 - Map of Nueva Ecija showing the municipality of Caranglan where Sitio Binbin, Barangay General Luna is located (insights.looloo.com)

\section{Results and Discussion}

\section{Socio Demographic Profile}

Most of the Kalanguya respondents were 26-45 years old (Table 1), female and married and is similar with other indigenous communities in Northern Luzon (Cabauatan, 2008). Like any other indigenous communities in the Philippines, many Kalanguya respondents reached elementary education (Table 2). This information is common not only to the indigenous communities, but to all Filipinos who are experiencing poverty. Jobs such as farming, slash and burn agriculture, sweep making and vending, were the sources of the families' meager annual income that ranges from $\mathrm{PhP}$ 10,000.00 and below, which marks their economic status below the poverty line (Table 2). However, even with poverty affecting the lives of the Kalanguya community, they still have large families. The majority of the community members have 5 to 10 members (Table 2) which is common to many poor families since they have a mindset that their children could provide additional means of support, particularly in providing livelihood for the family.

\section{Indigenous Knowledge on Mushroom and their Utilization}

Indigenous knowledge refers to the cumulative and complex bodies of knowledge know-how, practices and representations that are maintained and developed by local communities, who have long histories of interaction with the natural environment (UNESCO, 2003). The utilization of macrofungi as sources of food and medicine is established in all indigenous communities. In the Philippines, the knowledge is intrinsic among indigenous groups and is inherited from their great ancestors by oral communication (Balangcod \& Balangcod, 2009).

The Kalanguya respondents knew about mushrooms, they consider mushrooms as vegetables, locally called bagel and buo (Table 3). They also believe that mushrooms grew during the rainy season however, there were few who believe that mushrooms also appear during the cold months (Table 3). According to Reyes et al. (2003) mushrooms could grow anytime of the year in the Philippines as long as moisture is abundant. The Kalanguya community believed that mushroom grow in soil and decaying logs (Table 3), which is similar with the beliefs of the Aeta communities in Pampanga, Tarlac and Zambales (De Leon et al. 2012). Table 4 also shows that mushrooms were also mainly collected for food and rarely for medicine and other purposes such as insect repellant. Since most mushrooms were utilized for food, the cooking method preferred by the Kalanguyas for nearly all edible mushrooms were sautéed with other vegetables (Table 4) similar with the Aeta indigenous tribe (De Leon et al. 2012). During the rainy season, the community consumed more than one kilo of mushrooms, two to three times a week. 
Table 1 Socio Demographic Profile of the Kalanguya Respondents

\begin{tabular}{cccc}
\hline No of Respondents & \multicolumn{3}{c}{ Age } \\
& $\mathbf{1 6 - 2 5}$ & $\mathbf{2 6 - 4 5}$ & 46-up \\
\hline 20 & 2 & 10 & 8 \\
\hline
\end{tabular}

Table 2 Additional Information on the Socio Demographic Profile of the Kalanguya Respondents

\begin{tabular}{|c|c|c|c|c|c|c|c|c|c|c|c|c|c|c|c|}
\hline \multirow{2}{*}{$\begin{array}{c}\text { No of } \\
\text { Respondents }\end{array}$} & \multicolumn{5}{|c|}{ Educational Attainment } & \multicolumn{2}{|c|}{ Job } & \multicolumn{3}{|c|}{ No. of Family Members } & \multicolumn{5}{|c|}{ Annual Family Income } \\
\hline & College & Vocational & $\begin{array}{c}\text { High } \\
\text { School }\end{array}$ & Elementary & $\begin{array}{l}\text { No Formal } \\
\text { Education }\end{array}$ & $\begin{array}{l}\text { Blue } \\
\text { Collar }\end{array}$ & $\begin{array}{l}\text { White } \\
\text { Collar }\end{array}$ & $\begin{array}{l}4 \text { and } \\
\text { below }\end{array}$ & 5 to 10 & $\begin{array}{l}11 \text { and } \\
\text { above }\end{array}$ & $\begin{array}{c}10,000 \text { and } \\
\text { below }\end{array}$ & $\begin{array}{c}20,000- \\
40,000 \\
\end{array}$ & $\begin{array}{c}\mathbf{5 0 , 0 0 0 -} \\
\mathbf{7 0 , 0 0 0} \\
\end{array}$ & $\begin{array}{c}80,000- \\
100,000 \\
\end{array}$ & $\begin{array}{c}\text { above } \\
100,000\end{array}$ \\
\hline 20 & 0 & 2 & 4 & 13 & 1 & 18 & 2 & 2 & 17 & 1 & 11 & 4 & 3 & 1 & 1 \\
\hline
\end{tabular}

Table 3 Knowledge on Mushroom of the Kalanguya Respondents

\begin{tabular}{|c|c|c|c|c|c|c|c|c|c|c|c|c|}
\hline \multirow{2}{*}{$\begin{array}{c}\text { No of } \\
\text { Respondents }\end{array}$} & \multicolumn{2}{|c|}{$\begin{array}{l}\text { Do you know what } \\
\text { mushrooms are? }\end{array}$} & \multicolumn{4}{|c|}{ What is your local term for mushroom? } & \multicolumn{3}{|c|}{ When do mushrooms appear? } & \multicolumn{3}{|c|}{ Where do mushrooms appear? } \\
\hline & Yes & No & Bagel & Buo & Uong & $\begin{array}{l}\text { Multiple } \\
\text { Response }\end{array}$ & When it's raining & When it's hot & When it's cold & Soil & Decaying Logs & Leaf Litter \\
\hline 20 & 20 & 0 & 3 & 5 & 2 & 10 & 20 & 0 & 3 & 18 & 8 & 1 \\
\hline
\end{tabular}

Table 4 Survey of the Indigenous Beliefs of the Kalanguya Respondents on Mushroom Utilization and Cultivation

\begin{tabular}{|c|c|c|c|c|c|c|c|c|c|c|c|c|c|c|c|}
\hline \multirow{2}{*}{$\begin{array}{c}\text { No of } \\
\text { Respondents }\end{array}$} & \multicolumn{3}{|c|}{ How do you use mushroom? } & \multicolumn{2}{|c|}{$\begin{array}{l}\text { How do you } \\
\text { prepare it? }\end{array}$} & \multicolumn{3}{|c|}{ How do you cook it? } & \multicolumn{3}{|c|}{$\begin{array}{c}\text { How do you recognize edible } \\
\text { mushrooms? }\end{array}$} & \multicolumn{2}{|c|}{$\begin{array}{l}\text { Could mushrooms } \\
\text { be cultivated? }\end{array}$} & \multicolumn{2}{|c|}{$\begin{array}{c}\text { Have you tried } \\
\text { cultivating } \\
\text { mushroom? }\end{array}$} \\
\hline & Food & Medicine & Others & Cooked & Raw & Boiled & Grilled & Sautéed & Appearance & Smell & Origin & Yes & No & Yes & No \\
\hline 20 & 20 & 0 & 1 & 20 & 5 & 7 & 7 & 16 & 20 & 1 & 5 & 12 & 8 & 7 & 13 \\
\hline
\end{tabular}


Table 5 Mushrooms collected in the Kalanguya community in Bgry. General Luna, Sitio Binbin, Caranglan, Nueva Eijca

\begin{tabular}{lcc}
\hline \multicolumn{1}{c}{ Local Name } & Scientific Name & Traditional Uses \\
\hline 1. Bang-ugan & Meripilus giganteus & Food \\
2. Bugatan & Undetermined & Food \\
3. Buo & Scleroderma citrinum & Food \\
4. But-taytay & Microporus sp. & Food \\
5. Gum-gumot & Leucoagaricus cepaestipes & Food \\
6. Kuyupan & Podocypha brasiliensis & \\
7. Lingtan & Undetermined & Food \\
8. Uong usa & Undetermined & Food \\
9. Upot & Russula virscens & \\
10. Wek-wek & Undetermined & Food \\
\hline
\end{tabular}

They recognized edible species of mushrooms based on appearance and origin. They simply ignored inedible species (Table 4). Furthermore, they knew that mushrooms could be cultivated; other members of the community tried cultivating mushrooms (Table 4).

\section{Listing of Mushrooms Utilized by the Kalanguyas}

There were 36 records of macrofungi that are utilized by the Kalanguya tribe. However, during the collection, only 10 fungal species were seen and collected (Table 5). Molecular identification showed that some of the species collected were, Meripilus giganteus, Scleroderma citrinum, Leucoagaricus cepaestipes, Podocypha brasiliensis, Russula virescens and Microporus sp.

Fungal species were also used by indigenous people as food in Mexico (Garibay-Orijel et al. 2006, Montoya et al. 2004), Malaysia (Christensen \& Larsen, 2005), and Papua New Guinea (Sillitoe 1995). In Africa, various kinds of wild edible mushrooms were found, of which 15 to 25 species were locally well known and eaten throughout Zambia (Pegler \& Pierce, 1980).

\section{Acknowledgements}

This work was funded by DOST - PCHRD under the Tuklas Lunas Project of Central Luzon State University. We would like to thank also the Kalanguya tribe in Sitio Binbin who participated in this research endeavor.

\section{References}

Balangcod TD and Balangcod AKD 2009 - Ethnomedical knowledge of plants and healthcare practices among the Kalanguya tribe in Tinoc, Ifugao, Luzon, Philippines. Indian Journal of Traditional Knowledge 10 (2), 227-238.

Cabauatan JG 2008 - Ethnobotanical investigations among the five ethnic groups in the Northern Cagayan Valley. Dissertation University of Santo Tomas, Manila, Graduate School.

Cayat GC 2013 - Manuscript on Kalanguya Cultural Communities. Retrieved from http://ncca.gov.ph/about-culture-and-arts/articles-on-c-n-a/article.php?igm=4\&i=227

Christensen M, Larsen HO 2005 - How can collection of wild edible fungi contribute to livelihoods in rural areas of Nepal? Journal of Forest and Livelihood 4, 50-55.

De Leon AM, Reyes RG, dela Cruz TEE 2012 - An ethnomycological survey of macrofungi utilized by Aeta communities in Central Luzon, Philippines. Mycosphere 3(2), 251-259.

Dulunan A 2014 - Who are the Kalanguyas of Northern Luzon? Published in News. http://www.santafe.gov.ph/index.php/updates/news-articles/item/13-who-are-the-kalanguyasof-northern-luzon

Garibay-Orijel R, Cifuentes J, Estrada-Torres A, Caballero J - People using macrofungal diversity in Oaxaca, Mexico. Fungal Diversity 21, 41-67.

Montoya A, Kong A, Estrada-Torres A, Cifuentes J, Caballero J - Useful wild fungi of La Malinche National Park, Mexico. Fungal Diversity 17, 115 - 143. 
National Commision on Indigenous Peoples (NCIP) 2008 - "Ethno Group: Ifugao." Available at http://www.ncip.gov.ph/ethno_groupdetail.php?id=54. Accessed on 17 June 2008

Pegler DN, Pierce GD 1980 - The edible mushrooms of Zambia. Kew Bulletin 35, 475 - 491.

Reyes RG, Abella EA, Quimio TH 2003 - Wild macrofungi of CLSU. Journal of Tropical Biology 2, 8-11.

Sillitoe P 1995 - An ethnobotanical account of the plant resources of the Wola Region, Southern Highlands Province, Papua New Guinea, Journal of Ethnobiology 15, 201-235.

United Nations Educational Science and Cultural Organization (UNESCO) 2003 - Convention for the safeguarding of the intangible cultural heritage as a step towards safe guarding non-material cultural heritage. 